\title{
Entrepreneurship and Firm Formation Across Countries
}

\author{
Leora Klapper, Raphael Amit, Mauro F. Guillén and Juan Manuel Quesada *
}

Abstract: The World Bank Group Entrepreneurship Survey measures entrepreneurial activity around the world. The database includes cross-country, time-series data on the number of total and newly registered businesses for 84 countries. This paper finds significant relationships between entrepreneurial activity and indicators of economic and financial development and growth, the quality of the legal and regulatory environment, and governance. The analysis shows the importance of electronic registration procedures to encourage greater business registration. These results can guide effective policymaking and deliver new capabilities for identifying the impact of reforms.

JEL Classification: G18, G38, L51, M13

Key Words: Entrepreneurship, Business Statistics, Economic Development, Business Registries.

* Corresponding author: Leora Klapper, ph: 1-202-473-8738, e-mail: lklapper@worldbank.org. Amit and Guillén are at the Wharton School and Klapper and Quesada are at the World Bank. We are grateful for the financial support of the SME department at the IFC, the Development Research Group at the World Bank, and the Wharton Global Family Alliance, the Wharton-SMU Research Center, and the Penn Lauder CIBER Grant No P220A60017.. Thanks to Zoltan Acs, Maxwell Aitken, Laurence Carter, Tim Davis, Asli Demirguc-Kunt, Michael Ingram, Aart Kraay, Andrei Mikhnev, and participants the NBER conference on International Differences in Entrepreneurship for valuable comments and special thanks to Sagit Stern, Sharika Jain, Dennis Bogusz and Aaron Imperiale for their outstanding research assistance. This paper's findings, interpretations, and conclusions are entirely those of the authors and do not necessarily represent the views of the World Bank Group or the Wharton School. 


\section{Introduction}

Entrepreneurship is essential for the continued dynamism of the modern market economy and a greater entry rate of new businesses can foster competition and economic growth (Klapper, Laeven, and Rajan, 2007, Djankov, La Porta , Lopez de Silanes and Shleifer, 2002). In this regard, a comprehensive longitudinal study of entrepreneurial activity can assess time-varying and time-invariant determinants of firm-creation, and its relationship to economic growth and poverty reduction. Furthermore, from an evolutionary economics perspective, new research suggests that disparities in economic growth between advanced and less developed countries can narrow owing precisely to the growth of entrepreneurial activity (Galor and Michalopoulos, 2006). Empirical data can also help us better understand how entrepreneurs interact within their respective networks, wherein new business ideas are generated and businesses are created (Stuart and Sorenson, 2005). Additionally, there is a strong need to develop data sets to study how economic and political factors affect entrepreneurship. For instance, Brander, Hendricks, Amit, and Whistler (1998) used a longitudinal data set on the evolution of firm formation in Canada to document that economic growth is driven by new entry rather than by the growth of existing firms.

This study offers a methodology for collecting data on new business creation, serving as a first step in enabling research on the dynamic of entrepreneurial activity. Furthermore, the data can be used as a benchmark for changes in the composition of the private sector, and further advance the study of the impact of regulatory, political, macroeconomic, and institutional changes on entrepreneurship and growth.

We find that business entry and density rates are significantly related to country-level indicators of economic development and growth, the quality of the legal and regulatory environment, ease of access to finance, and prevalence of informality. In the multivariate panel analyses, we find that the business environment, specifically the ease of starting a business and political corruption, remain significant indicators of total firm registrations, even after controlling for the level of economic development. These results are thus consistent with prior work on the efficient allocation of inputs and other resources to entrepreneurial activities (Jovanovic 1982). We also find significantly higher entry rates in countries with better governance. These results can guide effective policymaking and deliver new capabilities for identifying the impact of reforms. 


\section{Methodology: How Do we Define Entrepreneurship?}

In order to measure entrepreneurship and make data universally comparable, we developed a methodology that can be applicable across heterogeneous legal regimes and economic systems. Previous efforts had been made in this regard, but the great majority focused solely on the developed world, and did not take into account differences in legal systems, sectors, and economic structures (see United Nations, 2005).

The definition of entrepreneurship lacks a common language (Outcalt, 2000). Joseph Schumpeter defined entrepreneurship as "the assumption of risk and responsibility in designing and implementing a business strategy or starting a business” (Schumpeter, 1949). J. W. Gough stated that entrepreneurship "refers to a person who undertakes and operates a new enterprise or venture, and assumes some accountability for the inherent risks” (Gough, 1969). For practitioners, entrepreneurship has generally been viewed as the process of creating new wealth. The entrepreneurial process centers on the discovery, creation and profitable exploitation of markets for goods and services. Therefore, and for the purposes of the analysis in this study, entrepreneurship is defined as:

The activities of an individual or a group aimed at initiating economic activities in the formal sector under a legal form of business.

Notably, this definition excludes informal sector initiatives. This exclusion is based on the difficulties of quantifying the number of firms in the informal sector, rather than on its relevance for developing economies (Boegh, Nielsen and Ploving, 1997). The only way to measure the informal sector is through economic censuses, which due to their high costs are infrequently collected. In addition, our goal is to measure the growth of the formal private sector, relative to the informal sector, and factors that encourage firms to transition to the formal sector.

After defining our measure of entrepreneurship, we need to create a standard unit of measurement. Generally, entrepreneurial activities are carried out in the form of a "business." Statistical agencies around the world define "business" in many different ways based on the sources of available administrative data (Vale, 2005). Due to the lack of a universally-agreedupon definition of what constitutes a business, agencies have formulated either an economic, 
statistical or legal definition. ${ }^{1} \quad$ For instance, the U.S. bases its business statistics on establishments, Canada reports Average Labor Units (ALU), ${ }^{2}$ while countries reporting to Eurostat $^{3}$ and UNECE ${ }^{4}$ use various measures including legal (enterprises), geographical (local unit), and activity-based (kind of activity unit) approaches for their business statistics. As a result, the data are not easily comparable across countries: the proposed unit of measurement must take into consideration the availability of the data, consistency across countries, relevance to entrepreneurship, and focus on the formal sector.

Hence, our definition of the unit of measurement of entrepreneurship is:

Any economic unit of the formal sector incorporated as a legal entity and registered in a public registry, which is capable, in its own right, of incurring liabilities and of engaging in economic activities and transactions with other entities.

There are no clearly-defined, internationally agreed-upon, minimum-size criteria for business activity (United Nations 2005). In this study, the aim is to collect the information of all businesses regardless of their economic or staff size.

\section{Business Registries}

The information presented in this study was collected from business registries and other government sources in 84 countries. These other sources include statistical agencies, tax and labor agencies, chambers of commerce, and private vendors (such as D\&B), which were used only when business registry data were unavailable or non-existent. ${ }^{5}$ While this analysis reasserts the great heterogeneity that characterizes these public entities in terms of inter alia, prevailing regulations, methodologies, and implantation of digital administration, a number of common challenges and achievements have been identified and are described in this section.

\footnotetext{
1 At the international level, Eurostat and the OECD have attempted to define the concept of business. Other countries like the United States, choose the establishment as the main unit for business statistical purposes.

${ }^{2}$ US Census Bureau: http://www.census.gov/econ/www. Also see Longitudinal Employment Analysis Program (LEAP) of Statistics Canada: http://strategis.gc.ca/epic/site/sbrp-rppe.nsf/en/rd00827e.html.

${ }^{3}$ Council Regulation (EEC) No 696/93 of 15 March 1993 on the statistical units for the observation and analysis of the production system in the Community, Official Journal L 076 , 30/03/1993 P. 0001 - 0011.

${ }^{4}$ Terminology on Statistical Metadata, United Nations Statistical Commission, available at: http://www.unece.org/stats/publications/53metadaterminology.pdf

${ }^{5}$ A complete list of sources is provided in Annex 1.
} 


\subsection{What are Business Registries?}

Business registries $^{6}$ are public entities generally established by commercial or business code mandates and managed by the Ministries of Commerce or Justice (Alfonso and Labariega, 2006). They are responsible for registering businesses, as well as noting any significant modification to the internal structure of these businesses throughout their life-span. The main purpose of business registries is to guarantee that businesses comply with current regulations and to make such information available to the public. Their composition varies greatly across countries, as is amply evidenced by the fact that they can either coexist with real estate registries (e.g. Mexico), be managed by chambers of commerce or professional associations (e.g. Syria), or be stand-alone agencies (e.g. U.K.).

\subsection{Who Must Register?}

While the laws for business registrations vary greatly across countries, a common thread among all is the "legal entity" element: any business with a legal entity (or "corporate personhood") separate from its owners must be duly registered. ${ }^{7}$ Thus, the definition of what constitutes a separate legal entity in a given country is key in deciding which businesses are required to register.

Within this context, most countries fall into one of the following legal system groupings:

(i) Civil Law systems: Every business constitutes a separate legal entity; therefore every business is required to register. ${ }^{8}$

(ii) Common Law systems: Only corporations and similar entities constitute autonomous legal entities, therefore mandatory registration is limited to the same.

Some examples of the distinctions between the two legal systems include:

- In Common Law countries, while every corporation constitutes a business, not every business constitutes a corporation.

- In Civil Law countries, every business is a corporation.

- Partnerships do not have a defined legal equivalent in Civil Law countries. Since partnerships and sole proprietorships can be considered businesses from an economic

\footnotetext{
${ }^{6}$ Also called Incorporation Offices (US), Companies Registration Offices (IR), Companies House (UK), Business Register (AU), Mercantile Registries (SP), Public Registries of Property and Commerce (MEX), Registry of Commerce (FR), etc.

${ }^{7}$ The registration of businesses without legal entity (e.g. professional associations, individual merchants, etc.) can be voluntary, not compulsory, in some countries (e.g. Spain).

${ }^{8}$ Some countries (e.g. Czech Republic) also require independent merchants to register.
} 
point of view; they do not represent a separate legal entity and are therefore not obligated to register. ${ }^{9}$

The great majority of the countries surveyed fall into one of these two categories. Nevertheless, there is a significant group that uses variations of the two systems. For instance, some have voluntary registration for business without legal entities, or the registration is business-activity based.

\subsection{What is Registered?}

The amount of information required to register varies across countries. However, in general, the common information requirements for corporations - and its counterparts in Civil Law systems - were identified as follows:

a) During the incorporation/registration process:

- Report of incorporation

- Articles and memorandum of association

- List of shareholders

- List of managing directors and their appointment

- Sample signatures of the managing directors

- Proof of payment of the required taxes and fees

- Proof of compliance with applicable business regulation

- Approval by the authorities if necessary (e.g. banks or insurance companies)

b) During the business life:

- Balance sheet and profit/loss accounts

- Facts concerning the contractual and legal capacity of bodies authorized to represent the business enterprise

- Changes in:

o the name of the company

o legal address of the company

o type of activity

o legal form

0 the articles of incorporation

o share capital, value of the share, amount of shares;

- Mergers, transformations, and divestitures

- Branch openings and closures

- Exclusion of personal liability in special cases

- Facts concerning insolvency proceedings

- Liquidations

- Re-registration requirements ${ }^{10}$

\footnotetext{
${ }^{9}$ Some Civil law countries require registration only if the legal equivalent of partnership is involved in certain activities (e.g. financial).

${ }^{10}$ For instance, following changes in sector classifications.
} 
However, many countries requiring businesses to file certain data lack the ability to enforce compliance. A key case in point is the fact that whereas $65 \%$ of the countries surveyed require businesses to record their financial statements, a significantly lower percentage actually manage to collect the data. The same applies to the reporting of closures: over $80 \%$ of the countries surveyed require notification of firm closures - either through liquidation, bankruptcy, merger, or acquisition - but a large number of countries lack the proper mechanisms to enforce this requirement. In sum, although information requirements do not vary markedly across countries, many registries lack enforcement mechanisms regarding business filing and reporting laws. This further contributes to the significant differences in the quality of the registration information across countries.

\subsection{Information Available to Customers}

In principle, registries are open to the public, therefore none of the information they contain is regarded as confidential. ${ }^{11}$ Nevertheless, the way in which customers access information and the format in which the information is presented varies greatly across countries. This variance is mainly a function of the degree to which registries have been digitalized, and to which an efficient accessing framework governing the system exists.

When the register has been successfully converted into electronic format, the information is generally available to customers through the internet for a small fee. If the country has not made such a transition, the client must generally go to the registry bureau (which is often decentralized) in person, and conduct "manual" research on site. To complement official channels, private vendors also distribute registry information in many countries (see Box 1).

\section{Box 1: Private sector initiatives}

Many private sector initiatives have developed in response to businesses' demand for information. In countries that have neither a central business registry nor electronic information available to the public, the private sector has attempted to fill the gap by creating databases containing the information that would normally be found in the business registry, such as contact information, a description of business activity, and the names of owners and managers. Some private vendors have specialized in building databases to evaluate the financial risk of businesses. Using financial statements, bankruptcy and insolvency notifications, and other court records, they produce reports

${ }^{11}$ Some countries do not disclose the articles of incorporation, or have more restrictive legislation because of privacy laws (e.g. Germany). 
that measure the credit and financial risk of businesses. The sources used for gathering this information vary greatly across countries and businesses, but commonly include public data at chambers of commerce, business registries, professional associations, and in some cases, telephone listings. Nevertheless, these databases, while widely used in some countries, may also be heavily monitored because of the possible conflicts with privacy rights. Some examples are D\&B (www.dnb.com) and Bureau Van Dijk (www.bvdep.com).

\subsection{The Role of Business Registries in Business Development}

An effective business registry has a direct impact on the way business is conducted in a country, as well as on investors' confidence. This section examines three specific roles a properly developed business registry could play:

a) Disseminator of information:

If a country implements a mechanism to facilitate the transmission of business information (i.e. through the Internet), then the business registry becomes an important vehicle in improving the way business in that country is done. This available information facilitates trade, enhances confidence among the business community, and fosters national and international business transactions. Moreover, registries serve as a store of data that facilitate the identification of potential clients and business opportunities, as well as a means to identify underdeveloped sectors.

In the case that the registry requires businesses to post financial statements and indicate bankruptcy procedures, it then becomes an important tool for gauging the integrity and financial risk of private businesses. This can facilitate access to commercial credit from banks, and help creditors and potential business partners make proper financial judgments. ${ }^{12}$ For instance, in many countries commercial banks rely on the information found in the business registry to perform a risk analysis of the business before approaching the company to offer their financial products.

\section{b) Legal watchdog:}

The business registry is at the front line in the effort to assure that a business operates transparently and within the bounds of the law. It acts as a guarantor of a solid, legal business environment by fostering transparency thereby aiding in preventing and exposing illegal activities such as money laundering and other financial crimes.

\footnotetext{
${ }^{12}$ For cross-country evidence see Berger, Klapper and Udell, 2001.
} 


\section{c) Policy tool for governments:}

In countries where firms are required to disclose annual financial reports, the registry is a key tool for shaping economic policies. ${ }^{13}$ It provides policymakers with a vast amount of information (number of employees, revenue, business strength, etc.) that can be used to better shape economic and labor policies. Moreover, this information can also provide indicators for monitoring and evaluation of public policies, projects, and presidential goals in order to measure their success and impact (see Box 2).

\section{Box 2: Business Indicators and Monitoring \& Evaluation}

Monitoring and Evaluation (M\&E) is becoming a key tool for governments to measure the impact and efficiency of their programs as well as the success of their presidential goals. Nevertheless, to have an autonomous and soundly institutionalized M\&E system at the national level, the government must implement a system that can supply a constant flow of pertinent, audited, and accurate information. Therefore, the data collected by government agencies becomes the base to design credible indicators for M\&E. In this regard, this study aims to identify a consistent methodology to define indicators for business demography, as well as to show the relation between business creation and economic development. Proving the relation between entrepreneurship and economic development (i.e. the impact of business creation on the reduction of the informal sector, GDP, etc.) highlights the relevance of entrepreneurship as an intermediate component for programs aimed to foster economic development.

The following chart illustrates the role of business demography indicators on a program aimed at poverty reduction. Although the log frame is oversimplified, it displays the different sets of indicators and the logic relation that takes place between the input and the goal, as well as the relevance of indicators for the monitoring and evaluation of the project.

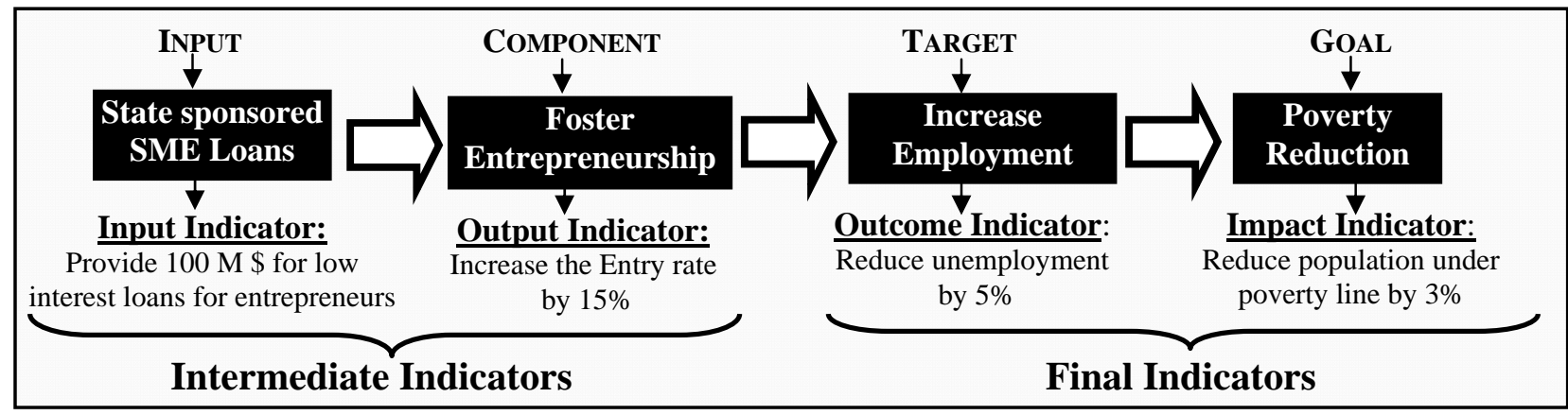

This example highlights that governments without a proper information-mechanism to measure entrepreneurship lack a valuable tool that could help them to better design, implement, and evaluate their programs.

\footnotetext{
${ }^{13}$ The decision to require mandatory public disclosure of financial statements for non-listed companies should be made independent of the potential use of the data for monitoring and benchmarking. For further discussion, see Gielen, et al. (2006).
} 


\subsection{Challenges to the Development of Business Registries}

Business registries have developed at a different pace across countries due mainly to two formidable challenges:

a) Modernization of public administration:

An innovative public administration with a digital modernization program would transfer all historical information collected by paper-format business registrars into electronic format and facilitate its access via the internet or similar media (known as e-distribution). It would also implement an electronic system where a business could register its company over the internet regardless of the necessary amount of legal physical paperwork - creating a "digital signature," thereby speeding up the entire process (known as e-registration). Currently, less than $35 \%$ of the countries outside the OECD have achieved this goal, yet many others are developing or implementing the necessary technological and legal infrastructure (i.e. electronic signature laws) to do so. For instance, the European Union First Initiative requires all EU countries to digitalize all their public registrars (see Box 3).

\section{Box 3: Supranational registries: The BRITE Project}

With the goal of establishing a dynamic business ecosystem, the European Union, in conjunction with the European Business Registry, has launched the "Business Register Interoperability Throughout Europe” (BRITE) project in 2006. BRITE aims to address the cross border registration problem in the EU by creating a common and unified European Business Registry. The main challenge is the interoperability of all EU registries through the implementation of a common electronic platform in 18 different countries. The objective of BRITE is to harmonize the collection and distribution of business registry data, in order to facilitate greater private and public sector access to corporate data. The goal is also to promote registry data as part of greater e-government initiatives.

Nevertheless, many countries continue to record their business information in paper format causing considerable difficulties as regards recording and accessing the data. The "paper version” makes the registrar susceptible to physical damage (i.e. humidity, weather, insects, etc.) and subject to possible misappropriation (i.e tracking difficulties, lost records .) (Ricardo de la Rosa Guzman 2003). In such instances, conducting research also becomes a formidable task. This is particularly the case if there is no central registry - given that each local registry tends to gather and classify the information according to its own methodology. Moreover, it has been observed that registry employees tend to use their own notation and indexing methods, eschewing standard methods, thereby creating a confusing mixture of notation and coding 
systems resulting in frequent errors and even fraud; furthermore, corruption and bribes can be commonplace, as clients may be asked to pay “a fee” for quicker service (Alfonso Labariega, 2006). This highlights the importance - and difficulties - of modernization in decentralized, developing countries.

\section{b) Centralization:}

When a country lacks an electronic centralized registry, access to information becomes problematic. In these cases - especially when the information is only available in paper format the client must necessarily revert directly to the region/state where the business had been incorporated in order to retrieve the information. Furthermore, many countries have laws governing registries at the federal level, but delegate the registration process and regulatory oversight to the regions/states. In this case, confusion arises when each register follows its own separate methodology, making the registration process as varied as there are regions/states within the country.

It is also common in strongly decentralized countries, especially those with a federal system, that companies be required to register in the state or region where they regularly conduct their business. This means that they must register in every state where they would like to open a subsidiary, which subsequently slows business transactions and acquisitions across regions.

\section{Challenges and Data Limitations}

Despite the effort made to minimize disparities and make the data comparable across countries, certain limitations preclude a completely systematic analysis of entrepreneurial development. The following represent the most frequently faced problems in the process of gathering and processing the data:

\subsection{Data Availability}

As previously stated, many countries do not compile data on newly-created and closed businesses, much less on re-registered businesses (i.e. businesses that register existing businesses because of changes to firm names, ownership, sector, etc.) A second challenge refers to some countries, excluded from this survey, which have in fact collected data on enterprise creation, but simply do not have the tools or resources to process them. In some cases, decentralized business 
registries make aggregation to the national level extremely difficult. In other cases, the data are archived only in paper format.

\subsection{Data "Purity"}

Time series data should be used with caution because the levels of total and newly registered businesses might be inflated due to recent legal or economic reforms. For instance, Algeria issued a new law requiring all existing businesses to reregister, in order to bring their status up to new sectoral requirements. As a result, the number of businesses doubled from 1997 to 1998 (Figure 1).

\section{Figure 1: Legal Reforms that Affect Business Statistics, the Algerian Case}

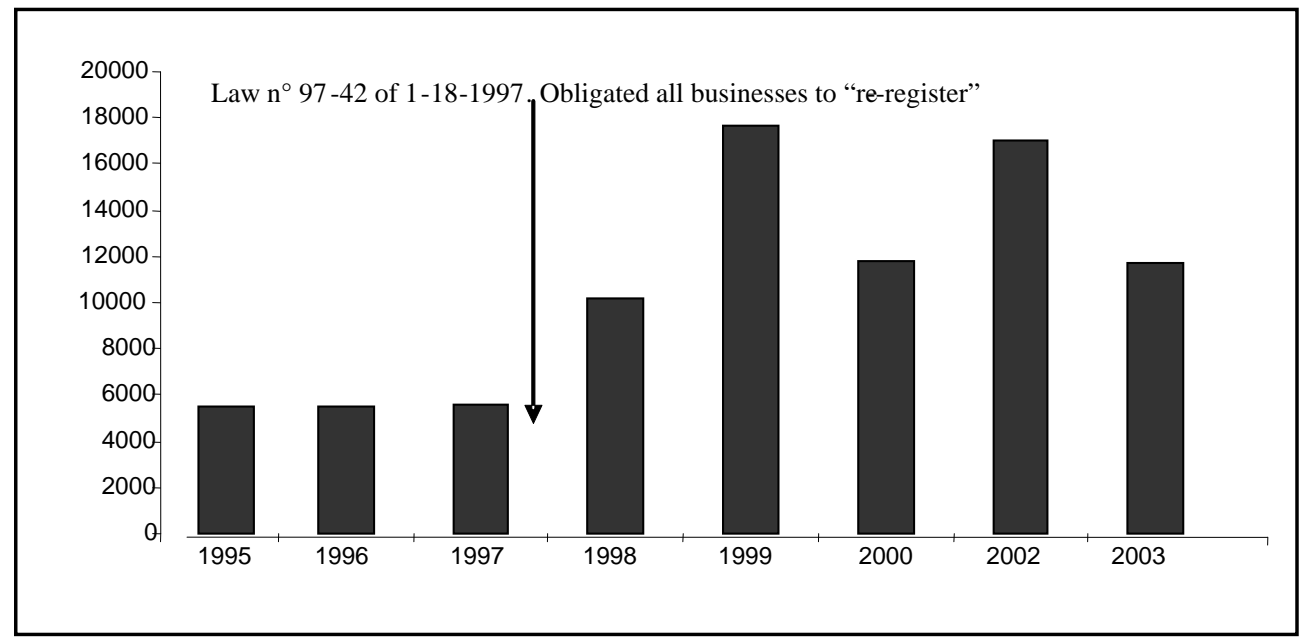

Source: World Bank Group Entrepreneurship Database, 2007.

\subsection{Limitations Regarding Data on Firm Closures}

As previously stated, although approximately $80 \%$ of surveyed countries require businesses to report closures; a significantly lower number were actually able to report the number of closed businesses. The reasons differ from country to country, but are mainly due to the fact that the registrars generally have no enforcement mechanisms to obligate businesses to report closures. In other cases, the number of closed businesses was reported, but might be imprecise because only a low percentage of businesses actually report their closure. Although the number of closed companies is essential to paint a clear picture of the economic and entrepreneurial activities of a country, it is not yet feasible to obtain comparable data (Nuci, 1999). 
Information on "active” companies - excluding closed or inoperative businesses - should be available from national tax agencies and labor ministries, although these agencies generally do not make their data public. A few countries, such as Denmark, maintain active registries that annually confirm that registered firms are still operating. This type of mechanism improves the accuracy of the data and their usefulness to creditors and business partners.

\subsection{Shell Corporations}

Shell companies are defined as companies that are registered for tax purposes, but are not active businesses. These corporations do not fit into the methodology of our study, since they do not correspond to the category of "entrepreneurship" or to that of "business" (see Box 4). Therefore, we also exclude some countries that are internationally recognized tax havens (i.e. Jersey).

\section{Box 4: Shell Corporations}

Shell companies are also known in Common Law countries as International Business Corporations, Personal Investment Companies, Inactive Corporations, Front Companies or Mail Box Companies. Generally incorporated in free zones or tax haven countries, the main characteristic is that they have no significant assets or operations, and usually have no employees. The purpose for their creation can vary:

Legal purposes: To protect business names or as an alternative venture financing mechanism (to obtain financing prior to starting operations)

Fraudulent purposes: Money laundering, tax evasion, etc.

In Civil Law countries, the incorporation of "inactive companies" is common in order to create "legal equivalents" of legal forms from the common law that have no direct equivalent in civil law systems. These "inactive corporations" are legally incorporated, but do not perform any significant economic activity. A clear example is the family that incorporates a business in order to unify the entirety of their real estate assets under a common name. If one of the members of the family dies, their shares are redistributed to the other shareholders at a significantly lower tax rate compared to that of an ordinary inheritance.

\subsection{Regional Data Limitations}

When comparing data across regions, it is important to note the relative difficulty in collecting information from developing countries. For the purpose of this study, we group countries in five different regions: (i) Asia, (ii) Africa and the Middle East, (iii) Eastern Europe and Central Asia, (iv) Latin America and the Caribbean, and (v) industrialized countries. 
Although the number of represented countries varies by region, we decided to include regional averages because the countries that did answer the questionnaire were considered representative enough of the region to give an approximate picture.

\section{Summary Statistics}

We collected information from 84 countries on the total number of registered businesses and from 82 countries on the number of new businesses, defined as businesses registered in the current year. All data used in this analysis are averages from 2003 to 2005. Annex 1 provides the complete list of data sources, by country. Country-level data is available at: http://www.ifc.org/ifcext/sme.nsf/Content/Resources.

\subsection{Total Business Density}

Total business density is calculated as the number of registered businesses as a percentage of the active population (age 15-64) in that year. Data are available for 84 countries. The differences among regions are pronounced, as shown in Figure 2. We find, on average, approximately 29 businesses for every 1,000 active individuals. Business density ranges from 23 per thousand in Australia to less than 1 in many low-income African countries. The highest density is found in the developed world with an average of 64 businesses for every 1,000 active individuals, whereas all the other regions have a density lower than 40 businesses for every 1,000 active individuals.

Figure 2: Average Business Density (per 1,000 active population), by Region, 2003-2005

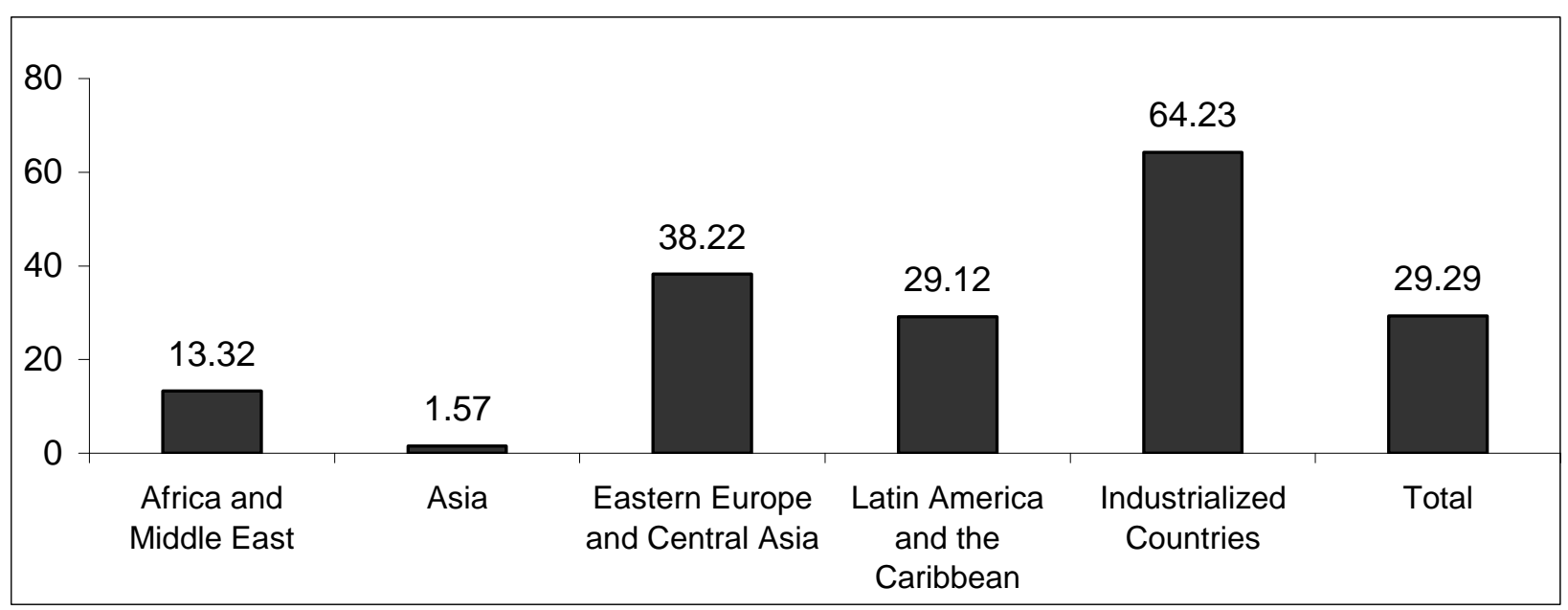

Source: World Bank Group Entrepreneurship Database, 2007. 


\subsection{Entry Rates}

Entry rates are calculated as new registrations of companies as a percentage of total lagged (previous year) registered businesses. The data for 82 countries, summarized by region, are shown in Figure 3. On a regional level, industrialized countries had the highest entry rates in the three years period. Interestingly, we find that mean entry rates are consistently around 7-9\% across emerging markets.

Figure 3: Average Entry Rates, by Region, 2003-2005

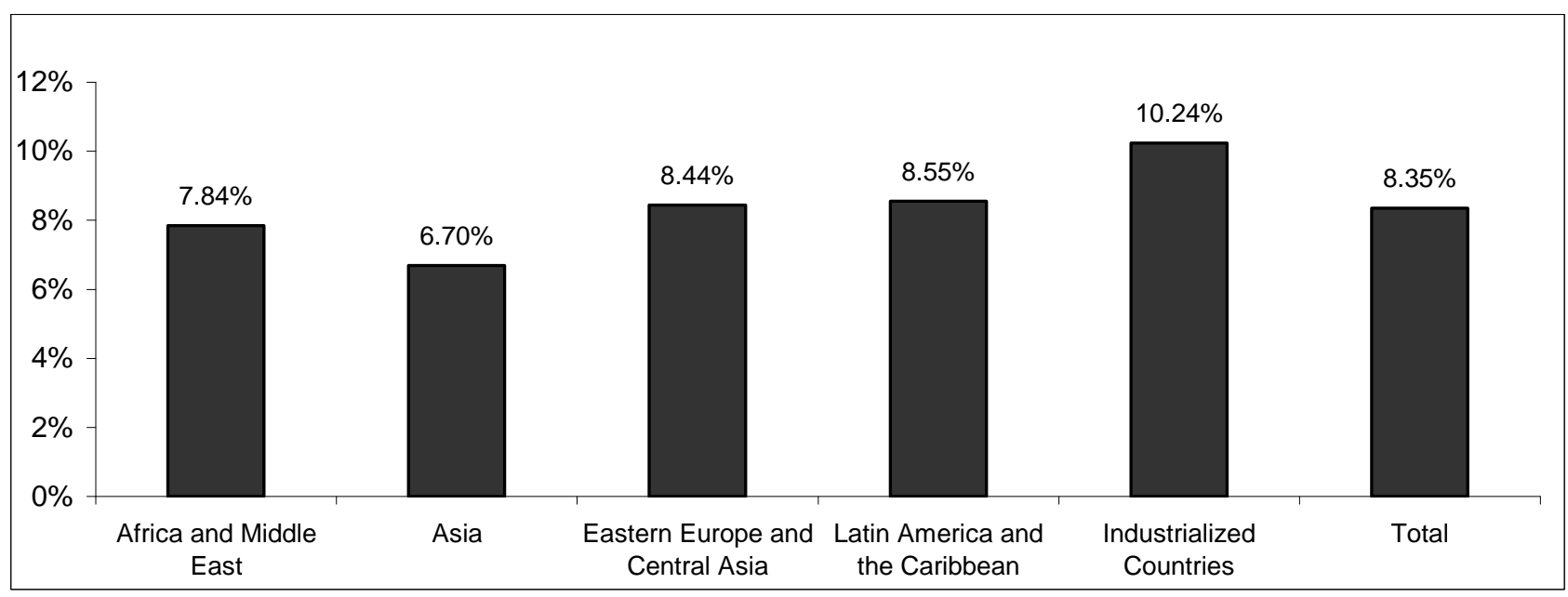

Source: World Bank Group Entrepreneurship Database, 2007.

\subsection{Business Distribution by Sector}

In order to gain a better understanding of the entrepreneurial phenomenon, the 2007 survey collected data on the number of total and new businesses disaggregated by sector of activity. In order to compare data across regions, the classification was truncated to: Wholesale and retail trade, Financial and real state, Industry, and Services.

An initial analysis of the data shows an almost perfect asymmetry in the business distribution in developing and industrialized countries (Figure 4). While in developing countries the retail and finance sectors are twice as big as in the industrialized countries, the industry and services sectors are half their size. Approximately the same distribution was found among new business created in 2005. 
Figure 4: Total Business Distribution, by Sector, 2003-2005

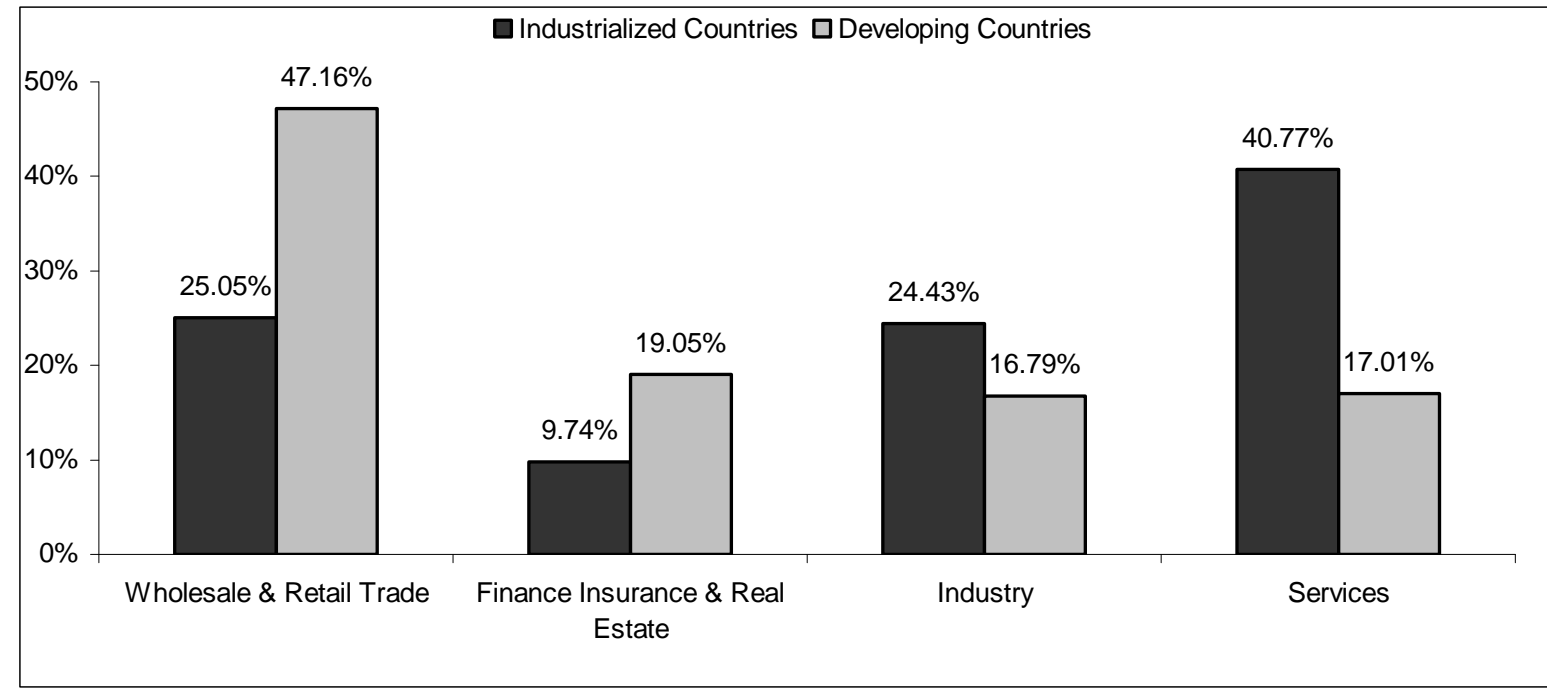

Source: World Bank Group Entrepreneurship Database, 2007.

An in-depth study would enable to better understand why entrepreneurs focus so disproportionably on certain sectors in developing countries. Nevertheless, a preliminary analysis might suggest the relative lower requirements of investment, human resources, knowledge, and capital as among the reasons that entrepreneurs in developing countries focus on the retail sector. In addition, in developing countries with costly and timely barriers to starting a business, firms in wholesale and retail trade might have the greatest incentive to formally register in order to receive a Value Added Tax (VAT) number, which might be required for domestic and international sales.

\section{Empirical Analysis}

In this section we examine various macroeconomic, financial, political, and regulatory indicators that might be related to business density and entry rates. Although we find significant relationships with these measures - i.e. more dynamic economies in countries with better business environments - we cannot postulate on the direction of causality. We plan to continue to collect this data over time and construct time-series of private sector entry and growth that will allow us to study the country characteristics that determine entrepreneurship and the effect of regulatory and institutional reforms. 


\subsection{Importance of the Business Environment}

Several results highlight the importance of the business environment for the growth and development of the private sector. For instance, the Doing Business Report, 2007 includes a ranking (from 1 to 175) of an "ease of doing business index," which measures the relative strength of the regulatory environment as conducive to the operation of business. The index is constructed as the simple average of the countries percentile rankings on 10 topics: Starting a business, Dealing with licenses, Employing workers, Registering property, Getting credit, Protecting investors, Paying taxes, Trading across borders, Enforcing contracts, and Closing a business. We find a negative and significant relationship between the ease of starting a business with the entry and density rates per country (Figure 5).

\section{Figure 5: Entry and Density Rates versus Ease of Doing Business Rankings, by Country, Average 2003-2005}
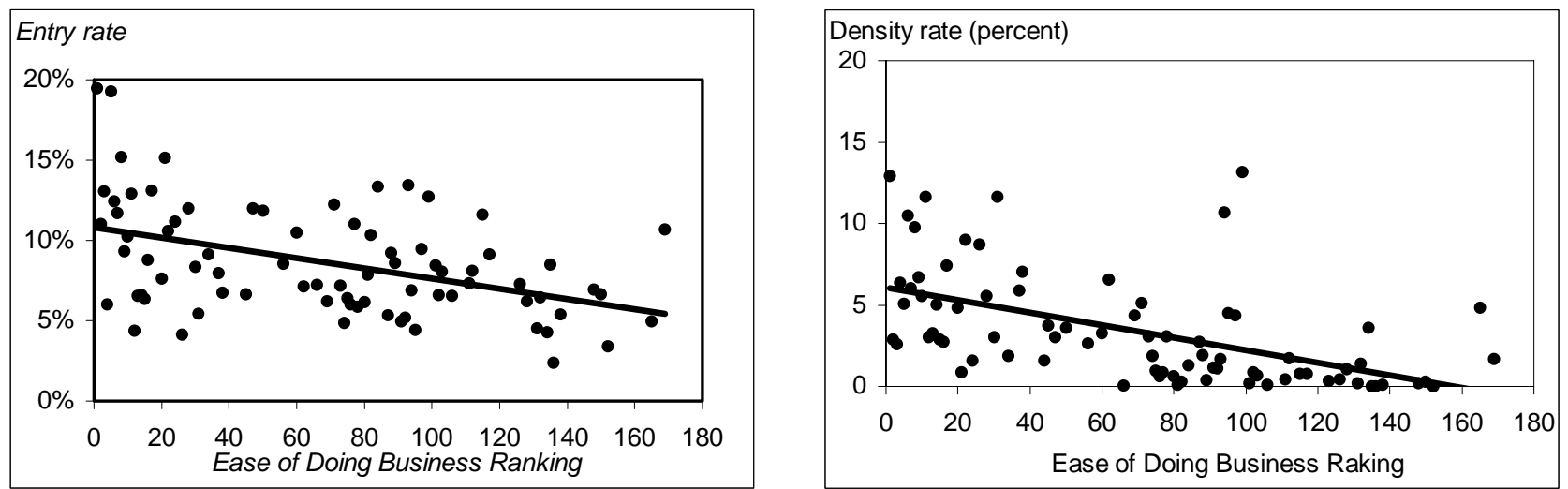

Source: World Bank Group Entrepreneurship Database, 2007.

More specifically, barriers to starting a business are significantly and negatively correlated with business density and the entry rate. For example, the fewer the procedures required to start a business, the greater the number of registered firms - and the higher the entry rate (Figure 6). There is also a significant relationship between the cost of starting a business (as a percentage of gross national income, or GNI) and business density and the entry rate (not shown). For example, for every 10 percentage point decrease in entry costs, density and the entry rate increase by about 1 percentage point. ${ }^{14}$

\footnotetext{
${ }^{14}$ Countries with entry costs greater than 40 percent of GNI per capita are excluded.
} 
Figure 6: Business Creation and the Number of Procedures to Start a Business, by Country, Average 2003-2005
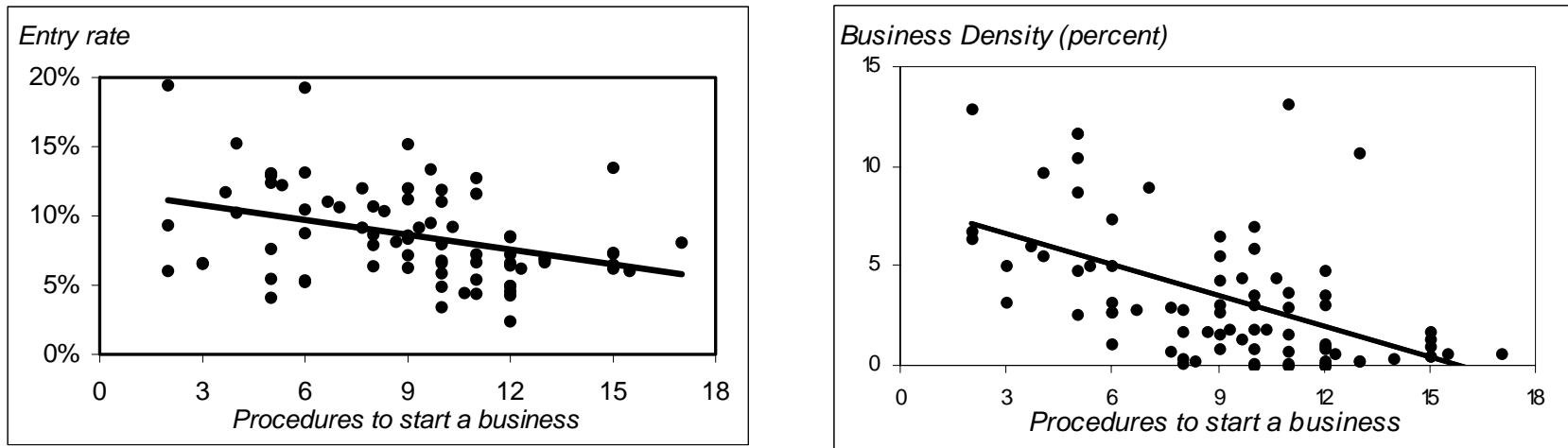

Source: World Bank Group Entrepreneurship Database, 2007.

\subsection{Economic and Financial Development}

The data also show a positive and significant relationship between economic and financial development and entrepreneurship. The log of GDP per capita and domestic credit to the private sector (as a percentage of GDP) are both positively and significantly correlated with entry rates (Figure 7) and business density (not shown). This suggests that greater business opportunities and better access to finance are related to a more robust private sector.

Disentangling the direction of causality - whether positive economic growth is a determinant for the creation (i.e. registration) of new businesses or whether greater entrepreneurship leads to economic growth and innovation - in an important area of future research.

\section{Figure 7: Entry Rates and GDP Per Capita and Private Credit to GDP, by country, Average 2003-2005}
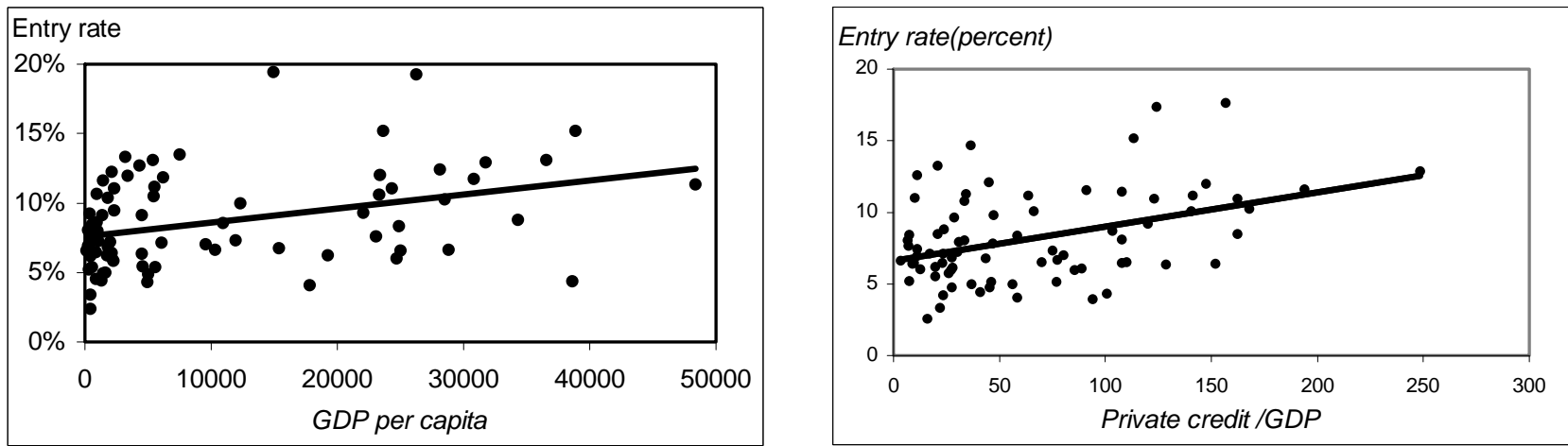

Source: World Bank Group Entrepreneurship Database (2007) and World Bank (2005). 


\subsection{Relationship with the Informal Sector}

Total firm registrations are significantly higher in countries with a smaller informal sector (Figure 8). This suggests a substitution effect and a larger informal sector in countries with higher entry barriers. The data also show a significant relationship between the entry rate and the informal sector.

Together, these results suggest that an increase in total and newly registered firms might indicate a decrease in the size of the informal sector. Indeed, a 30 percentage point increase in business density and a 10 percentage point increase in entry rates are commensurate with a 10 percentage point decline in the informal sector (as a share of GDP). We do not include this variable in the multivariate analysis because of its very large (about 80\%) and significant relationship with GDP per capita.

Figure 8: Business Creation and the Informal Sector, by Country, Average 2003-2005
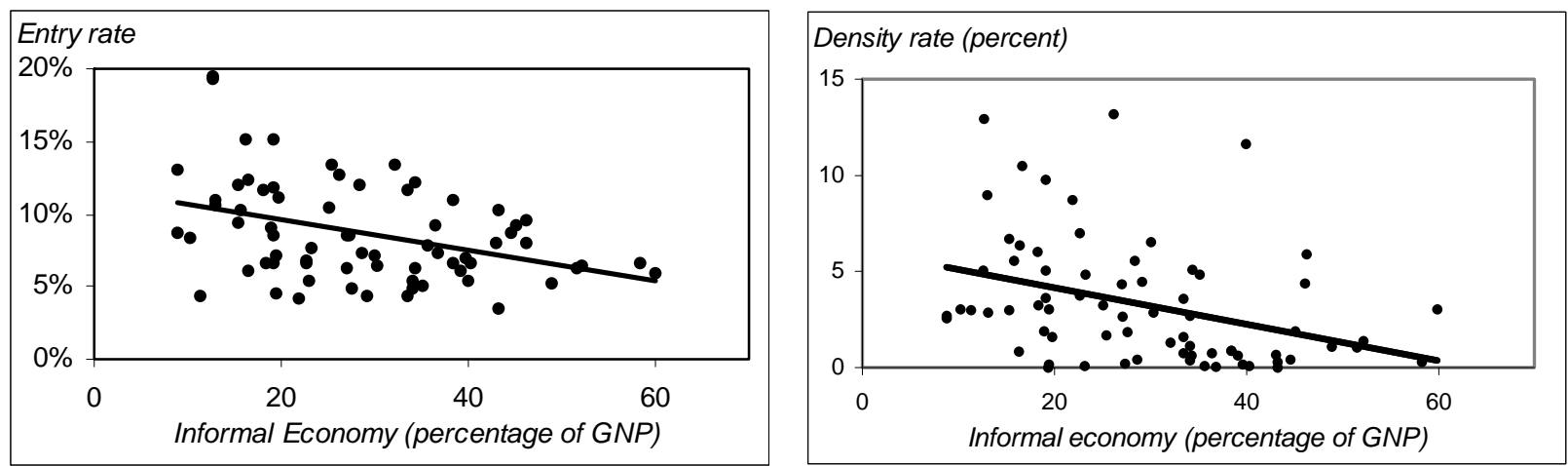

Source: World Bank Group Entrepreneurship Database and World Bank (2006).

\subsection{Business Creation and Governance}

In order to study the relation between Governance and entrepreneurship, we use the average of the six Kauffman, et al. (2007) governance indices: Voice and Accountability, Political Stability, Government Effectiveness, Regulatory Quality, Rule of Law and Control of Corruption. The data show a strong and significant relationship between entry rates and good governance (Figure 9). 
Figure 9: Entry rates and Kraay’s Governance Indicators, by Country, Average 2003-2005
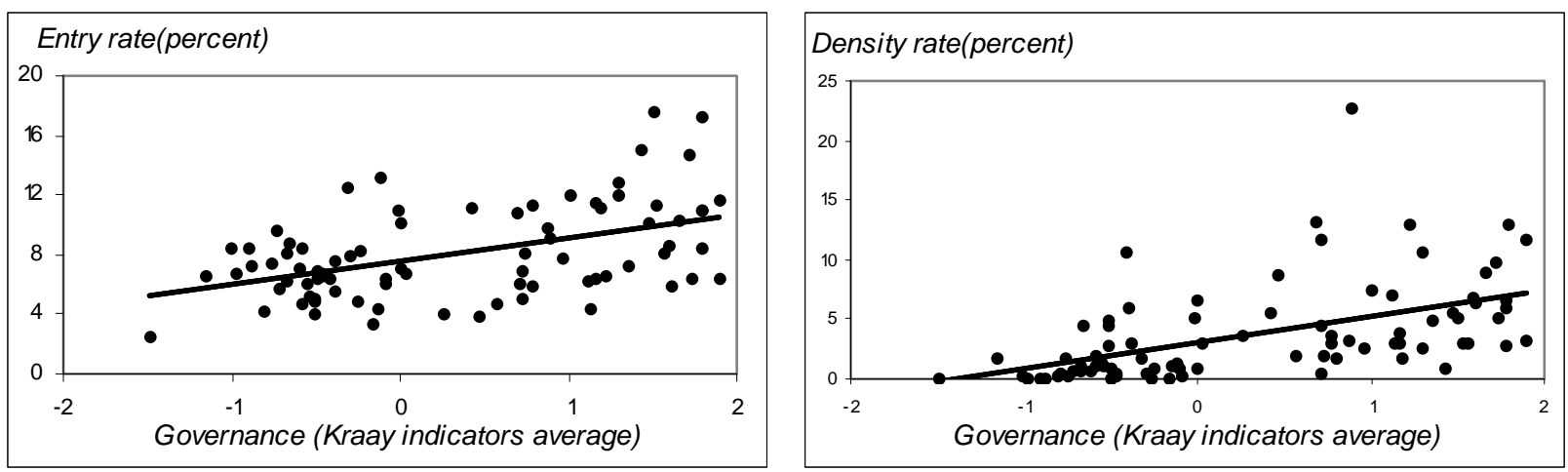

Source: World Bank Group Entrepreneurship Database and World Bank (2006).

This result suggests that a stable business environment should be expected to foster private sector development and growth. The case of Peru shows the sensitivity of new firm registrations to political changes (Figure 10).

Figure 10: Entrepreneurship and Political Stability - The Peruvian Case

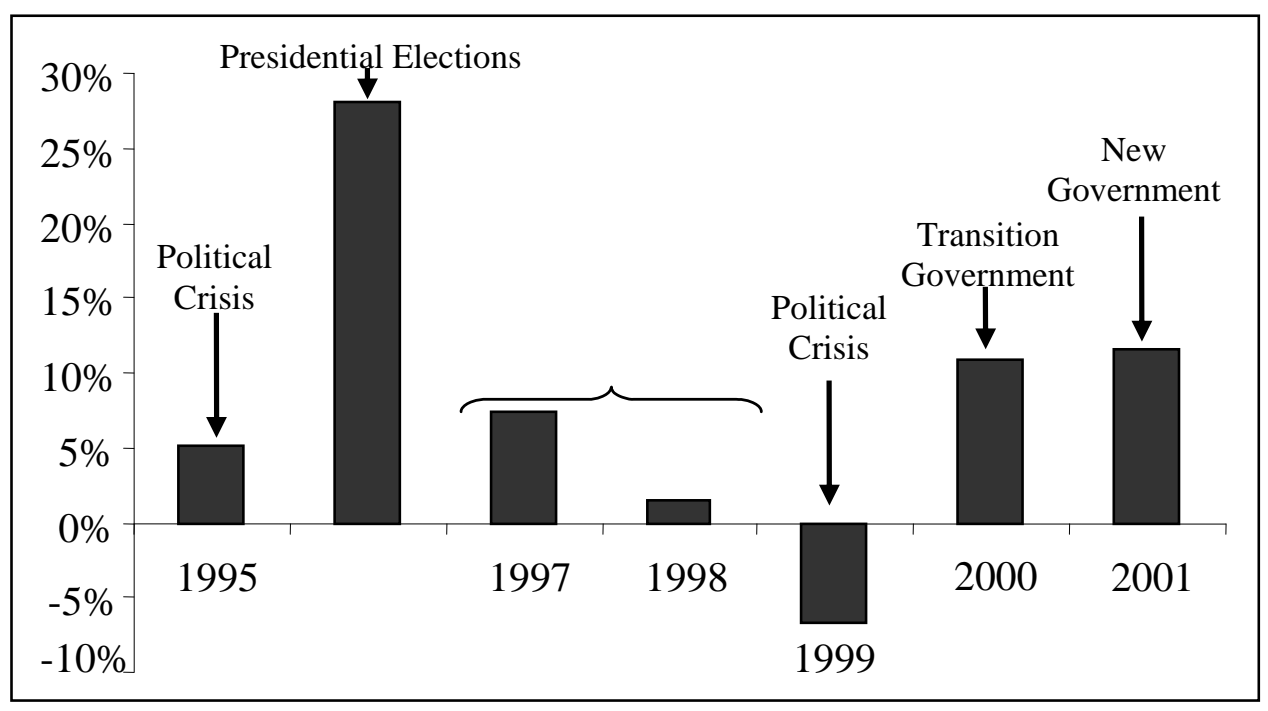

Note: Bars show the year-on-year percentage increase of new businesses.

Source: World Bank Group Entrepreneurship Database and World Bank (2007).

\subsection{Multivariate Analysis Using the Panel Data}

We use as predictors of entrepreneurial activity the country characteristics defined in Table 1. The sample for the analysis is a pooled, cross-sectional, longitudinal unbalanced panel of 197 observations across 76 countries with non-missing explanatory variables for 2003, 2004, 
and 2005. ${ }^{15}$ We use three measures of entrepreneurship as our dependent variables: Business density, Entry rates, and Entry per capita, which is defined as new firms as a percentage of the active population. While entry rates proxy new company formation compared to the existing stock of existing companies, entry per capita captures new company formation relative to the population, thus capturing the extent to which a country was entrepreneurial during a given year regardless of the previous (or cumulative) history of net company formation. Thus, it measures a different aspect of entrepreneurial activity.

Our explanatory variables include three indicators of the business environment, which vary over time. First, we proxy the barriers to entry he number of procedures to start a business and the rigidity of employment index, and an indicator of governance. We control in all analyses for policy stability, the ratio of domestic credit to GDP, and GDP per capita.

Table 1: Definitions and Summary Statistics, Panel of 76 Countries, 2003-2005

\begin{tabular}{|l|c|l|c|c|}
\hline \multicolumn{1}{|c|}{ Variable } & Obs & \multicolumn{1}{|c|}{ Description } & Mean & Std. Dev. \\
\hline ENTRY & 197 & $\begin{array}{l}\text { New registered corporations during year t divided by } \\
\text { existing stock of corporations as of end of year t-1 }\end{array}$ & 0.09 & 0.04 \\
\hline ENTRY PER CAPITA & 197 & $\begin{array}{l}\text { New registered corporations during year t divided by } \\
\text { population (000s) }\end{array}$ & 34.43 & 33.51 \\
\hline BUSINESS DENSITY & 197 & $\begin{array}{l}\text { Stock of corporations as of end of year t divided by } \\
\text { population (000s) }\end{array}$ & 3.25 & 4.06 \\
\hline ENTY PROCEDURES & 197 & Log of number of entry procedures (Doing Business) & 2.07 & 0.49 \\
\hline RIGIDITY OF EMPLOYMENT & 197 & Rigidity of employment index (Doing Business) & 36.97 & 16.85 \\
\hline GOVERNANCE & 197 & Average of governance indicators (Kauffman, et al.) & 0.33 & 1.00 \\
\hline DOMESTIC CREDIT (\% GDP) & 197 & Domestic credit divided by GDP (WB statistics) & 62.01 & 53.69 \\
\hline GDP PER CAPITA & 197 & Log of GDP per capita, PPPs, 2000 int'l dollars (WB) & 9.01 & 1.13 \\
\hline
\end{tabular}

Source: World Bank Group Entrepreneurship Database and World Bank (2007).

Table 2 shows the correlation matrix, with asterisks identifying statistical significance. These univariate tests show that business density (Column 3) is significantly related to all

\footnotetext{
${ }^{15}$ We exclude from this analysis six countries that are not included in the Doing Business database.
} 
country characteristics; however, entry rates are more sensitive to the business environment and governance. We also find large and significant correlations among our dependent variables.

Table 2: Correlation Matrix, Panel of 76 Countries, 2003-2005

\begin{tabular}{|l|c|c|c|c|c|c|c|}
\hline & $(1)$ & $(2)$ & $(3)$ & $(4)$ & $(5)$ & (6) & (7) \\
\hline ENTRY (1) & & & & & & & \\
\hline ENTRY PER CAPITA (2) & $0.2728^{* * *}$ & & & & & & \\
\hline BUSINESS DENSITY (3) & $0.574^{* * *}$ & $0.8731^{* * *}$ & & & & & \\
\hline ENTRY PROCEDURES (4) & $-0.2425^{* * *}$ & $-0.5545^{* * *}$ & $-0.5505^{* * *}$ & & & & \\
\hline RIGIDITY OF EMPLOYMENT (5) & $-0.2566^{* * *}$ & $-0.1457^{* *}$ & $-0.2573^{* * *}$ & $0.3153^{* * *}$ & & & \\
\hline GOVERNANCE (6) & $0.3721^{* * *}$ & $0.5286^{* * *}$ & $0.5431^{* * *}$ & $-0.6322^{* * *}$ & $-0.2811^{* * *}$ & & \\
\hline DOMESTIC CREDIT (\% GDP) (7) & $0.1297^{*}$ & $0.3988^{* * *}$ & $0.3472^{* * *}$ & $-0.5107^{* *}$ & $-0.3475^{* * *}$ & $0.7031^{* * *}$ & \\
\hline GDP PER CAPITA (8) & $0.3096^{* * *}$ & $0.5504^{* * *}$ & $0.4753^{* * *}$ & $-0.5349^{* * *}$ & $-0.1633^{* *}$ & $0.8173^{* * *}$ & $0.7066^{* * *}$ \\
\hline
\end{tabular}

Note: Asterisks, *, **, and ${ }^{* * *}$, indicate significance at $10 \%, 5 \%$, and $1 \%$, respectively.

Source: World Bank Group Entrepreneurship Database and World Bank (2007).

We use two different estimation methods: random-effects GLS and population-averaged Generalized Estimating Equations (GEE). In the latter a year trend was added as a control. In fixed-effects specifications (not shown) most of the variation in the sample was accounted for by the country dummies, thus providing no additional insight into the determinants of new firm registrations.

Table 3 presents the regression results based on the panel data. We find that entry rates are significantly related to better governance, even after controlling for GDP per capita. This finding is robust to the estimation method used, i.e. GLS or GEE. This suggests that government corruption and enforcement is the driving force in the decision of entrepreneurs to join the formal sector. Next, we find that entry per capita is significantly related to the number of entry procedures, access to finance, and economic development. This measure of new firm formation is independent of the previous history of entrepreneurship; hence, it is not surprising that GDP per capita turns out to be an important predictor. Finally, we find that business density is strongly and significantly related to lower barriers to entry and better governance (in the GEE model). These findings spotlight the importance of the business environment in formal private sector development and growth. 
Table 3: Regressions Predicting Entry Rates and Density, Panel of 76 Countries, 2003-2005

\begin{tabular}{|c|c|c|c|c|c|c|}
\hline & (1) & (2) & (3) & (4) & (5) & (6) \\
\hline & $\begin{array}{c}\text { ENTRY } \\
\text { [GLS] }\end{array}$ & $\begin{array}{c}\text { ENTRY } \\
\text { [GEE] }\end{array}$ & $\begin{array}{c}\text { ENTRY } \\
\text { PER } \\
\text { CAPITA } \\
\text { [GLS] } \\
\end{array}$ & $\begin{array}{c}\text { ENTRY } \\
\text { PER } \\
\text { CAPITA } \\
\text { [GEE] } \\
\end{array}$ & $\begin{array}{c}\text { DENSITY } \\
\text { [GLS] }\end{array}$ & $\begin{array}{c}\text { DENSITY } \\
\text { [GEE] }\end{array}$ \\
\hline PROCEDURES & $\begin{array}{l}-0.008 \\
{[0.34]}\end{array}$ & $\begin{array}{c}-0.0044 \\
{[0.59]}\end{array}$ & $\begin{array}{l}-5.0875 \\
{[0.07]^{*}}\end{array}$ & $\begin{array}{c}-8.6206 \\
{[0.11]}\end{array}$ & $\begin{array}{c}-1.6417 \\
{[0.00]^{* * *}}\end{array}$ & $\begin{array}{l}-1.2862 \\
{[0.05]^{*}}\end{array}$ \\
\hline RIGIDITY EMPLOYMENT & $\begin{array}{c}-0.0003 \\
{[0.27]}\end{array}$ & $\begin{array}{c}-0.0002 \\
{[0.41]}\end{array}$ & $\begin{array}{c}-0.1003 \\
{[0.42]}\end{array}$ & $\begin{array}{c}-0.0577 \\
{[0.74]}\end{array}$ & $\begin{array}{c}-0.0125 \\
{[0.52]}\end{array}$ & $\begin{array}{c}-0.0232 \\
{[0.27]}\end{array}$ \\
\hline GOVERNANCE & $\begin{array}{c}0.0125 \\
{[0.06]^{*}}\end{array}$ & $\begin{array}{c}0.0178 \\
{[0.01]^{* *}}\end{array}$ & $\begin{array}{c}-1.9257 \\
{[0.53]}\end{array}$ & $\begin{array}{l}3.8461 \\
{[0.44]}\end{array}$ & $\begin{array}{l}0.6388 \\
{[0.23]}\end{array}$ & $\begin{array}{c}1.3942 \\
{[0.02]^{* *}}\end{array}$ \\
\hline DOMESTIC CREDIT & $\begin{array}{c}-0.0001 \\
{[0.14]}\end{array}$ & $\begin{array}{c}-0.0001 \\
{[0.11]}\end{array}$ & $\begin{array}{c}0.0665 \\
{[0.03]^{* *}}\end{array}$ & $\begin{array}{l}0.0278 \\
{[0.62]}\end{array}$ & $\begin{array}{l}0.0008 \\
{[0.89]}\end{array}$ & $\begin{array}{c}-0.0045 \\
{[0.52]}\end{array}$ \\
\hline GDP PER CAPITA & $\begin{array}{l}0.0058 \\
{[0.32]}\end{array}$ & $\begin{array}{l}0.0028 \\
{[0.63]}\end{array}$ & $\begin{array}{c}16.4294 \\
{[0.00]^{* * *}}\end{array}$ & $\begin{array}{c}10.9955 \\
{[0.01]^{* *}}\end{array}$ & $\begin{array}{c}1.1195 \\
{[0.02]^{* *}}\end{array}$ & $\begin{array}{l}0.6106 \\
{[0.25]}\end{array}$ \\
\hline YEAR & & $\begin{array}{c}0.0047 \\
{[0.00]^{* * *}}\end{array}$ & & $\begin{array}{l}1.0996 \\
{[0.11]}\end{array}$ & & $\begin{array}{c}0.2736 \\
{[0.00]^{* * *}}\end{array}$ \\
\hline Constant & $\begin{array}{l}0.0682 \\
{[0.19]}\end{array}$ & $\begin{array}{c}-9.4265 \\
{[0.00]^{* * *}}\end{array}$ & $\begin{array}{c}-101.469 \\
{[0.00]^{* * *}}\end{array}$ & $\begin{array}{c}-2,250.14 \\
{[0.10]^{*}}\end{array}$ & $\begin{array}{c}-3.0723 \\
{[0.50]}\end{array}$ & $\begin{array}{c}-547.17 \\
{[0.00]^{* * *}}\end{array}$ \\
\hline $\begin{array}{l}\text { Observations } \\
\text { R-squared } \\
\text { Wald Chi-squared } \\
\end{array}$ & $\begin{array}{l}197 \\
0.19\end{array}$ & $\begin{array}{c}197 \\
38.89 * * * \\
\end{array}$ & $\begin{array}{l}197 \\
0.32\end{array}$ & $\begin{array}{c}197 \\
56.42^{* * *} \\
\end{array}$ & $\begin{array}{l}197 \\
0.34\end{array}$ & $\begin{array}{c}197 \\
63.67^{* * *} \\
\end{array}$ \\
\hline
\end{tabular}

Note: Variables are defined in Table 1. z-scores are shown in brackets beneath regression coefficient. Asterisks, *, $* *$, and $* * *$, indicate significance at $10 \%, 5 \%$, and $1 \%$, respectively.

Source: World Bank Group Entrepreneurship Database and World Bank (2007).

\section{Business Registries and Electronic Business Registration (EBR)}

Many governments have taken action to make it easier for entrepreneurs to start a new firm, such as deregulating and automating the registration process, which can reduce time and cost for entrepreneurs. ${ }^{16}$ A larger number of formally registered firms is associated with a smaller informal sector, which is associated with slower growth and employment and lower tax

\footnotetext{
${ }^{16}$ Cross-country data on the cost, time, and number of procedures required to register a business is available in the Doing Business Report: www.doingbusiness.org.
} 
revenue. ${ }^{17}$ Furthermore, formal sector registration provides firms access to a VAT sales ID, which offers greater domestic and international sales opportunities. Legislative reforms to the registration process have been shown in countries around the world to increase entry and small business employment (i.e. Mexico and Russia). ${ }^{18}$ An example of legislative reform to encourage formal entrepreneurship and the growth of new and small firms is to introduce on-line electronic registration systems. Automating the registration process also helps provide lenders, suppliers, and customers greater access to information on the financial health, management, and ownership of registered firms, which encourages greater access to financing and growth.

In order to have a better understanding of the business registration process and the impact of different typologies of registries in the ease of doing business, the 2007 World Bank Group Entrepreneurship Survey added a special section related to the business registries. Seventy-five countries participated in this section, providing valuable information about the registration processes, information requirements, and the availability of e-registries and e-distribution, among other issues.

\subsection{Business Registry Typology}

In order to asses the different degrees of modernization of business registries, the survey collected information on the availability of electronic registration, which broadly includes the automation and computerization of local registrars, the ability to register over the Internet, and electronic distribution of data via the Internet. However, this does not necessarily include online authentication or integration of e-government services. ${ }^{19}$ Figure 11 shows the deep disparity found between industrialized and developing countries. While on average only 32\% of developing countries have implemented an electronic registry, more than $80 \%$ of the industrialized countries have already achieved complete automation. However, in most regions over $60 \%$ of countries make registrar information available over the internet. This discrepancy might be explained by the fact that electronic distribution is less expensive and difficult to implement and does not require electronic signature or security laws or complex e-government platforms.

\footnotetext{
${ }^{17}$ For example, see Djankov, La Porta , Lopez de Silanes and Shleifer, 2002.

${ }^{18}$ See Seira, Kaplan, and Piedra, 2007 and Yakovlev, E, E. Zhuravskaya, 2007, for studies on the effect of registration reform on entrepreneurship in Mexico and Russia, respectively.

${ }^{19}$ For further information on EBR see "Implementing Electronic Business Registry (e-BR) Services," World Bank, 2007.
} 
Figure 11: Electronic Business Registration, by Region

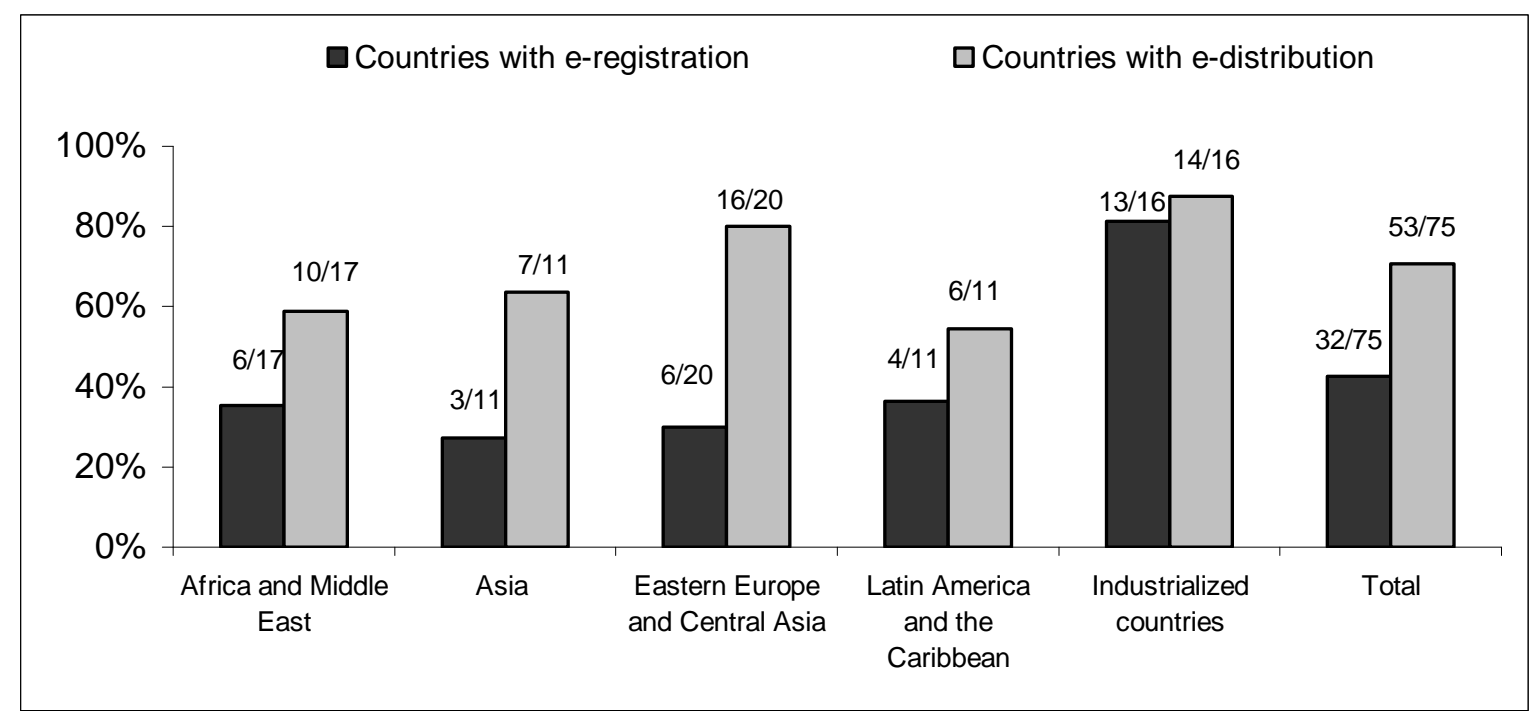

Source: World Bank Group Entrepreneurship Database, 2007.

Moreover, the registries were questioned on the information businesses were required to file, as well as if they registered any other information besides business incorporations. We find deep disparities among regions (not shown). When it comes to the information the companies are required to register, the majority of them oblige businesses to report closures and annual financial statements. Nevertheless, not all countries have the mechanisms to enforce these requirements. In addition, while business registries in industrialized countries tend to stand alone, and only in some cases register internet domains, developing countries tend to have registries where businesses, real state, internet domains and patent registrations coexist.

\subsection{Impact of E-Registry on the Ease of Doing Business}

Once the typology of the registry is defined, the survey aimed at understanding how different typologies impact entrepreneurship and the ease of doing business. In this regard, the data show that countries with e-registries tend to have shorter incorporation time frames, with less bureaucratic and cheaper procedures. For instance, the number of days necessary to incorporate a business is on average $21 \%$ lower in countries with e-registries, and the number of procedures is 23\% lower, as shown in Figure 12. 


\section{Figure 12: E-Registration and the Investment Climate}

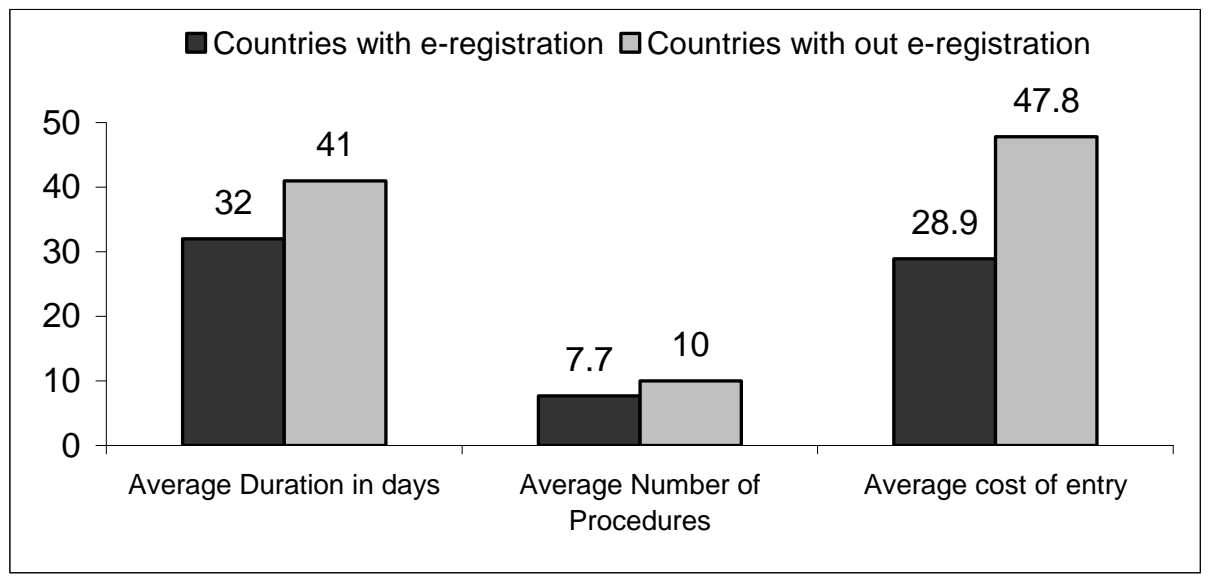

Source: World Bank Group Entrepreneurship Database, 2007.

\subsection{Impact of e-registration on entry rates:}

The data also reveal a significant role of modernized business registries in facilitating business creation. We find higher entry rates - defined as the number of new registrations divided by the stock of existing registrations - in those countries with e-registries compared to the ones without them. However, we cannot dismiss reverse causality, i.e. that registry modernization is demand-driven by a more robust private sector.

\subsection{The Impact of Electronic Registration: Guatemala, Sri Lanka and Jordan.}

The modernization of business registries is an important step in a successful private sector development strategy. If appropriate political and economical reforms take place, the country will require an efficient registry that can satisfy new businesses demands. Otherwise, the registry will become a bottleneck for entrepreneurs, not only encumbering the business creation process, but also discouraging the transition between the informal and formal sectors.

Our data suggest that the modernization process of business registries is usually a long process framed inside a larger national private sector development strategy. On average, countries draft five-year plans and the goal is to implement electronic registration and distribution. Figure 13 shows the timeline of new business registrations for three countries Guatemala, Sri Lanka, and Jordan - that have successfully implemented a business registry modernization strategy. 
The data suggest a strong relationship between the implementation of a modern business registry and a significant increase in the number of new business registered. All three countries witnessed an increase larger than $20 \%$ in the number of new business registration after the full implementation of their modernization plans. It is also noteworthy that in Jordan and Guatemala, the growth of new firms begins before the implementation of the reform, usually about 4 years earlier when the modernization plan was announced and initiated.

Figure 13: Number of New Businesses Incorporated

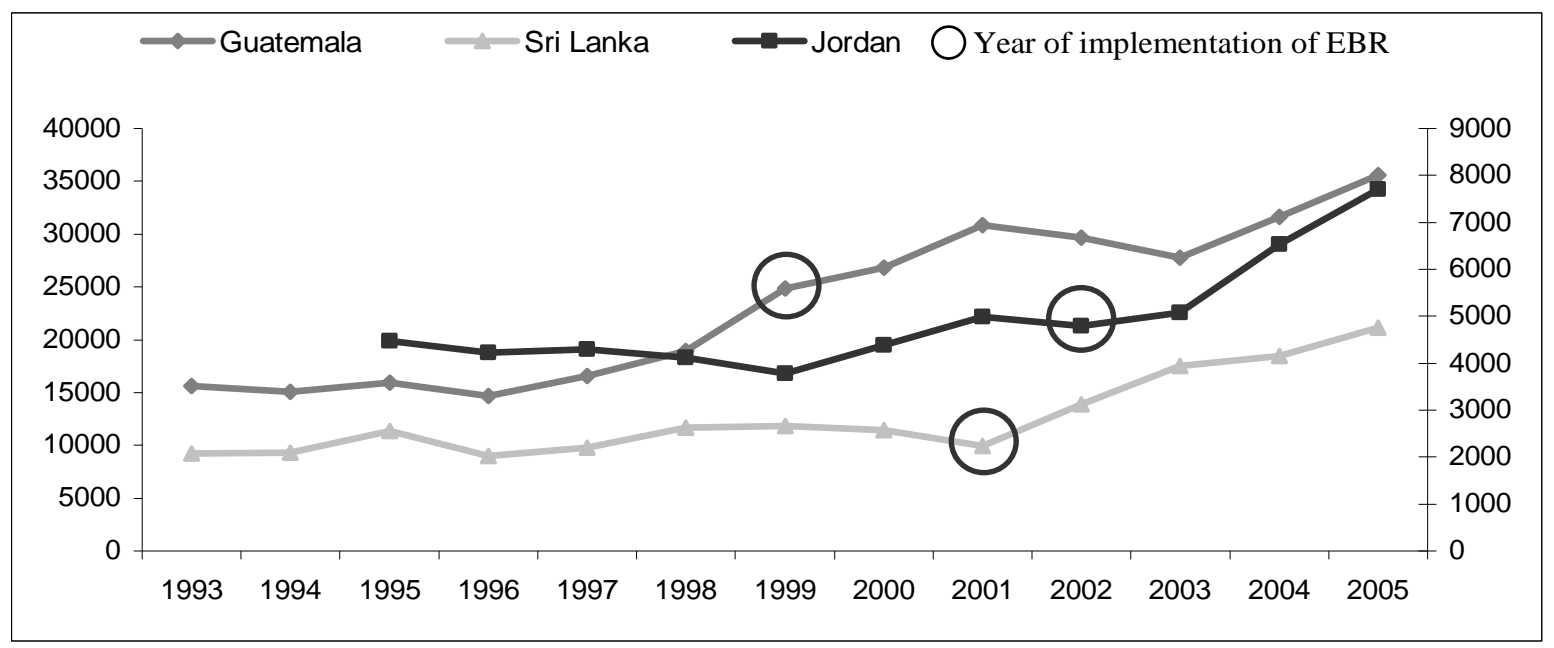

Source: World Bank Group Entrepreneurship Database, 2007.

For example, Guatemala began its modernization plan in 1996, achieving e-registration and e-distribution in 1999 (see Box 5). Jordan, following a 1997 law, created a new entity in charge of business registration and entrepreneurship promotion that fully implemented the electronic registration in 2002. Sri Lanka, on the other hand, partially implemented its electronic business registration in 2001, in order to prepare for the new Companies Act of 2007.

In addition, in several countries the business registry has played a central role in private sector development strategies. Instead of being a passive actor, the registries have in many cases been entrusted with the task of fostering entrepreneurship through a variety of activities. Among others tasks, they provide an advisory role training potential entrepreneurs, are in charge of the dissemination of information, promote foreign investment, reduce bureaucratic barriers, etc. 


\section{Box 5: The case of Guatemala}

Since the creation of the business registry of Guatemala in 1971, its structure remained almost unchanged for two decades. An average of seven employees and a couple of mechanical typewriters composed its organizational structure until 1995. In 1996, under a new administration, the Business Registry undertook an ambitious modernization plan. The initial program, divided into four phases, would be accomplished with the implementation of e-registry and e-distribution in 1999 (Figure 14)..

Figure 14: EBR Implementation in Guatemala

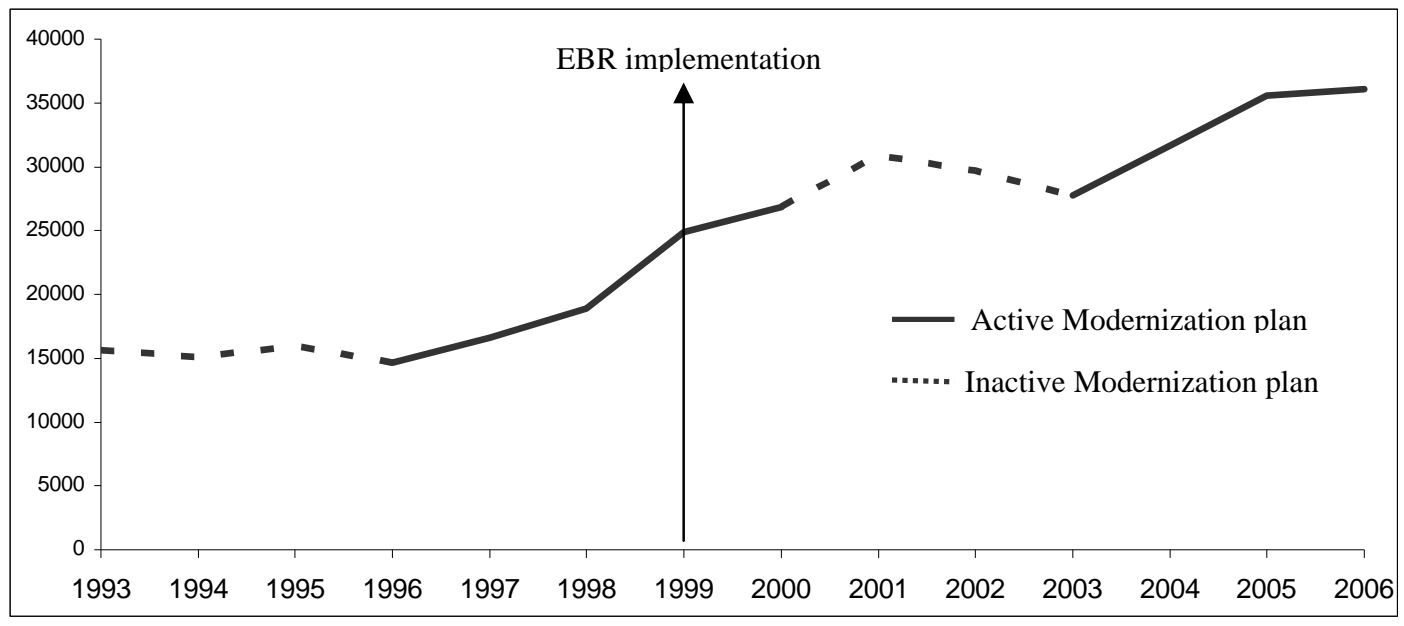

Source: World Bank Entrepreneurship Group Database (2007).

The plan included not only the modernization of the business registry, but also the entrustment of the registry as the central actor for the new private sector development strategy. The registry would gain an active role in the promotion of entrepreneurship through activities such as training of entrepreneurs, investment promotion, dissemination, etc. As shown in Figure 2, the modernization of the business registry and the new economic policies had a direct impact in the number of new business registered, with an increase of $40 \%$ on new registrations. In comparison, the three years period (2000-2003) during which the modernization strategy was paralyzed due to a change in the administration, resulted in a sharp $11 \%$ decline in the number of new business registered.

In 2003, the new administration reactivated the second modernization plan for the business registry. A number of new and ambitious goals were defined, such as increasing the number of registration locations, the reduction of necessary steps for business incorporation, and the promotion of foreign investment. This second stage had a remarkable impact in the number of new business incorporated, and increased the number of new business registered per year by almost 25\%. Moreover, the number of monthly electronic transactions - including incorporations, closures, re registrations and consultations - has climbed over 3400, representing more than $50 \%$ of the total number of monthly transactions. 


\section{Conclusion}

The World Bank Group Entrepreneurship Survey 2007 provides a new set of indicators to study the relationship between business creation, the investment climate, and economic development. Preliminary findings suggest that a higher level of entrepreneurship significantly relates to greater economic development, formal sector participation, and better governance. For instance, countries with lower barriers to entry and less corruption generally see higher percentages of firm registrations and entry. Consistent with the findings of Brander et al. (1998) for the Canadian economy, we find that in the 84 countries included in our analysis, entrepreneurship, measured both in terms of new registrations and entry rates, is also positively correlated with economic growth. This might suggest that countries that facilitate entrepreneurship see commensurate increases in overall economic growth and an expansion of the formal sector. Alternatively, it might be the case that periods of economic expansion encourage optimism and entrepreneurship; for instance, individuals might be willing to leave their job security to start a business if they are more confident they could find another job if their business fails. We hope to continue collecting data on firm creation over time, which will allow us to better understand how the private sector behaves over business and financial cycles. The current data limitations prevent us from observing the evolution of new entrants over time in order to asses their longevity and their growth. Furthermore, entrepreneurship indicators can be used to complement other World Bank group indicators - such as the Doing Business indicators

- in the development of policy recommendations to promote private sector development and growth.

In addition, the data collected could become the base for further studies in business ecology. For instance, the distribution of businesses per sector could be used for a deeper research paper aimed to answer questions such as which kind of businesses are easier to incorporate in challenging business environments, which sectors are interdependent on one another, and which ones contribute more to the countries economic development.

Moreover, the process of collecting data has become a valuable tool for the diagnosis of the business environments. For instance, direct contact with business registries in more than a 125 countries helps us to better understand the difficulties that entrepreneurs face when incorporating a business, as well as the impact of the institutional and technological framework of registries in the ease of starting a business. 


\section{$\underline{\text { References }}$}

Amaral, A., and R.Baptista, 2006. Serial vs. One-Business Entrepreneurs: A Longitudinal Investigation of Entry into Serial Entrepreneurship. University of Lisbon working paper.

Audretsch, D., B., Meijaard, and E. Stam, 2005. Renascent Men or Entrepreneurship as a One-Night Stand: Entrepreneurial Intentions Subsequent to Firm Exit. CEPR Discussion Paper No. 5342.

Beck, T., A. Demirgüç-Kunt, and R. Levine, 2004. SMEs, Growth, and Poverty: CrossCountry Evidence. Journal of Economic Growth, forthcoming.

Berger, A., L. Klapper and G. Udell, 2001. The Ability of Banks to Lend to Informationally Opaque Small Businesses. Journal of Banking and Finance.

Djankov, S., La Porta, R., F. Lopez-de-Silanes, and Shleifer, A., 2002. The regulation of entry. Quarterly Journal of Economics 117, 1-35.

James Brander, J, K. Hendricks, R. Amit and D.Whistler 1998. The Engine of Growth Hypothesis: On the relationship between firm size and employment growth

de la Rosa Guzmán, H.R., 2003. La Modernización en México del Registro Publico de Comercio. CINDER working paper.

EUROSTAT, 2006. Código de las Buenas Practicas de la Estadística Europea. Instituto Nacional de Estadística working paper.

Galor, O. and M. Stelios, 2006. The Evolution of Entrepreneurial Spirit and the Process of Development. Brown University working paper.

Giannella, V., 2006. Business Register Interoperability Throughout Europe: The BRITE Project. BRITE working paper.

Gielen, F., A. C. Hirata Barros, and G. Kusz, 2006. The Disclosure Dilemma: An Examination of Mandatory Public Disclosure of Financial Statements for Non-Listed Companies. World Bank discussion paper.

Gordon, R., 2006. Do Tax Rates Encourage Entrepreneurial Activity? IMF Working Paper No. 97/88.

Henisz, W. J. 2000. “The Institutional Environment for Economic Growth.” Economics and Politics, 12:1-31.

Jovanovic, B. 1982. "Selection and the Evolution of Industry," Econometrica 50, 642670. 
JW Gough, 1969. “The Rise of the Entrepreneur” Schocken Books, New York

Kaufmann, D., A. Kraay and M. Mastruzzi, 2006. Governance Matters V: Governance Indicators for 1996-2005. World Bank Policy Research Working Paper No. 4012.

Klapper, L., L. Laeven, R. Rajan, 2006, Entry Regulation as a Barrier to Entrepreneurship. Journal of Financial Economics 82:3, 591-629

Klapper, L., Juan Manuel Quesada Delgado, 2007. Understanding entrepreneurship: Influences and consequences of business creation. World Bank Viewpoint.

Knott, A. M. and H. Posen, 2005. Is Failure Good? Strategic Management Journal, 26(7), 617-641.

Labariega Villanueva, P.A., 2006, Devenir Historico del Registro Publico de Comercio. Boletín Mexicano de Derecho Comparado, Number 115.

MacDougal, P. and B. Oviatt, 2000. International Entrepreneurship: The Intersection of Two Research Paths. Academy of Management Journal.

Nielsen, P.B. and Ploving, J., 1997. Concepts used in statistical business registers in view of globalization and the informal economy. Statistics Denmark, International Statistical Review, 351-363.

Alfred R. Nucci1, 1999. "The Demography of Business Closings," Small Business Economics, Springer Netherlands, vol. 12(1), pages 25-39.

Outcalt, C., 2000. The Notion of Entrepreneurship: Historical and Emerging Issues. CELCEE Kauffman Center for Entrepreneurial Leadership working paper.

Sarasvathy, S. and A. Menon, 2003. Failing Firms and Successful Entrepreneurs: Serial Entrepreneurship as a Temporal Portfolio. Darden Business School working paper.

Schumpeter, J.A., 1911. Theorie Der Wirtschaftlichen Entwicklung. Duncker \& Humblot, Leipzig.

Stuart, T. and O. Sorenson, 2005. Social Networks and Entrepreneurship, in Handbook of Entrepreneurship Research: Disciplinary Perspectives, New York, Springer Science+Business Media.

United Nations, 2003. Small and Medium-Sized Enterprises in Countries in transition. ECE/TRADE/337/OPA/AC.32/1.

United Nations, 2005. Recommandations Internationales concernant les statistiques de l'activité économique. E/ESCAP/CPR(2)/9, Commission Économique er Sociale pour l'Asie et le Pacifique, November. 
Vale, S., 2005. International Data on Business Starts-ups: Factors Affecting Comparability. OECD working paper. 


\section{Annex 1: Sources, by Country}

\begin{tabular}{|c|c|}
\hline Country & Source \\
\hline Albania & Boga \& Associates Attorneys at Law \\
\hline Algeria & Centre National du Registre du Commerce \\
\hline Argentina & INDEC \\
\hline Armenia & National Statistical Service \\
\hline Australia & Business Demographics Section \\
\hline Austria & Bundesministerium für Justiz \\
\hline Azerbaijan & Ministry of Justice \\
\hline Bangladesh & Registrar of Joint Stock Companies \& Firms (RJSC) \\
\hline Belgium & Business Register \\
\hline Bolivia & Fundación para el Desarollo Empresarial \\
\hline Bosnia \& Herzegovina & IFC \\
\hline Botswana & Registrar of Companies \\
\hline Canada & Statistics Canada \\
\hline Chile & Servicio de Impuestos Internos \\
\hline China & Ministry of Commerce. State Administration for Industry and Commerce \\
\hline Colombia & Confecamaras \\
\hline Congo, Dem. Rep. & Djunga and Risasi, Attorneys at Law \\
\hline Costa Rica & Registro Nacional \\
\hline Croatia & Financial Agency (FINA) \\
\hline Curacao & Curaçao Chamber of Commerce \\
\hline Cyprus & $\begin{array}{l}\text { Ministry of Commerce, Industry and Tourism. } \\
\text { Department of Registrar of Companies and Official Receiver }\end{array}$ \\
\hline Czech Republic & Ministry of Justice. Czech Statistical Office \\
\hline Denmark & Danmarks Statistik \\
\hline Egypt & Commercial Registry Authority \\
\hline El Salvador & Dirección del Registro de Comercio \\
\hline Estonia & Centre of Registers, Ministry of Justice of Estonia \\
\hline Finland & Business Register \\
\hline France & Institut National de le Statistique et des Etudes Economiques \\
\hline Georgia & Ministry of Economic Development \\
\hline Germany & Statistisches Bundesamt \\
\hline Ghana & Registrar-General's Department. Ministry of Justice \\
\hline Greece & Athens Chamber of Commerce - ACCI \\
\hline Guatemala & Registro Mercantil \\
\hline Haiti & Direction Général des Impôts (DGI) \\
\hline Hong Kong, China & Companies Registry. Inland Revenue Department \\
\hline Hungary & Hungarian Central Statistical Office, Business Register Unit \\
\hline Iceland & Statistics Iceland \\
\hline India & Dun \& Bradstreet Information Services India Private Limited \\
\hline Indonesia & Ministry of Trade \\
\hline Ireland & Companies Registration Office \\
\hline Israel & Registry of Companies \\
\hline
\end{tabular}




\begin{tabular}{|c|c|}
\hline Country & Source \\
\hline Italy & InfoCamere \\
\hline Jamaica & Registry of Companies \\
\hline Japan & Ministry of Justice \\
\hline Jordan & Companies Control Department \\
\hline Kazakhstan & Agency of Statistics of the Republic of Kazakhstan \\
\hline Kenya & Iseme, Kamau \& Maena Advocates \\
\hline Latvia & Ministry of Justice \\
\hline Lebanon & Etude Badri et Salim El Meouchi \\
\hline Lithuania & State Enterprise Center of Registers. Department of Register of Legal Entities \\
\hline Luxembourg & Répertoire des Entreprises \\
\hline Macedonia FYR & Macedonia Statistics Office \\
\hline Madagascar & Direction Générale Statistique. Ministère de l'économie, des finances et du budge \\
\hline Malawi & Registry General \\
\hline Malta & Registrar of Companies \\
\hline Mexico & Mexican Statistical Agency and Labor Ministry \\
\hline Moldova & State Registration Chamber \\
\hline Morocco & Office Marocain de la Propriété \\
\hline Mozambique & National Director of the Registry and Notary Offices. Central Investment Center \\
\hline Netherlands & Dutch Association of Chambers of Commerce \\
\hline New Zealand & New Zealand Companies Office \\
\hline Nigeria & Corporate Affairs Commission \\
\hline Norway & Brønnøysundregistrene \\
\hline Oman & Company Registrar's Office, Department of Industry \\
\hline Pakistan & The Securities and Exchange Commission (SEC) \\
\hline Panama & Instituto Nacional de Estadistica \\
\hline Peru & Ministerio de Economia y Finanzas \\
\hline Poland & World Bank \\
\hline Portugal & Centro de Formação dos Registos e do Notariado. Ministry of Justice \\
\hline Romania & Registrar of Corporations. Office of the Attorney General \\
\hline Russia & Russian SME Resource Center \\
\hline Senegal & Agence Nationale de la Statistique et de la Démographie (ANSD) \\
\hline Serbia \& Montenegro & Department for Statistical Registers and Standards \\
\hline Singapore & $\begin{array}{l}\text { Accounting and Corporate Regulatory Authority (ACRA) } \\
\text { Business Statistics Division, Singapore Department of Statistics }\end{array}$ \\
\hline Slovak Republic & Analyses and Information Service Unit, Statistical Office of the Slovak Republic \\
\hline Slovenia & AJPES \\
\hline South Africa & Companies and Intellectual Property Registration Office \\
\hline Spain & Registro Mercantil Central de Madrid \\
\hline Sri Lanka & Board of Investment of Sri Lanka. Registrar of Companies \\
\hline Sweden & Swedish Companies Registration Office \\
\hline Switzerland & Eidg. Amt für das Handelsregister \\
\hline Syria & Federation of Syrian Chambers of Commerce \\
\hline Tanzania & Business Registration and Licensing Authority (BRELA) \\
\hline Thailand & World Bank \\
\hline Togo & Direction Générale de la Statistique et de la Comptabilité Nationale du Togo \\
\hline
\end{tabular}




\begin{tabular}{|l|l|}
\hline Country & Source \\
\hline Tunisia & Répertoire National d'entreprises \\
Turkey & Turkish Statistical Institute (TURKSTAT) \\
Uganda & Registrar General's Department \\
Ukraine & State Statistics Committee of Ukraine \\
United Kingdom & International Relations Manager at the Companies House \\
United States & D\&B \\
Yemen & Deputy Minister for Trade Affairs \\
Zambia & World Bank \\
Zimbabwe & Office of the Chief Registry of Deeds and Companies, Ministry of Justice \\
\hline
\end{tabular}

